\title{
PELAKSANAAN KEBIJAKAN PEMBELAJARAN BERBASIS ONLINE (MEDIA GOOGLE CLASSROOM) DALAM TANGGAP WORK FROM HOME MASA PANDEMI VIRUS COVID-19 DI FAKULTAS EKONOMI DAN ILMU SOSIAL UNIVERSITAS ISLAM NEGERI SULTAN SYARIF KASIM RIAU
}

\author{
Pivit Septiary Chandra \\ Fakultas Ekonomi dan Ilmu Sosial UIN Sultan Syarif Kasim Riau \\ pivit.s.chandra@uin-suska.ac.id
}

\begin{abstract}
The application of learning with the online system is a consequence of the spread of the Covid-19 Virus in the world of education. Google Classroom is a medium to help educators / teachers in the learning process. This has also been applied in the Faculty of Economics and Social Sciences. There are potential obstacles in the online learning process using google classroom in Uin Suska riau environment, therefore researchers are interested in researching the application of the learning system using Google classroom. This study used a descriptive qualitative method with survey techniques. The study was conducted on October 5, 2020, December 15, 2020, with the number of respondents as many as 390 students in the Faculty of Economics and Social Sciences, UIN Suska Riau. Data obtained through questions distributed to all respondents in the form of google form then the data is analyzed with a description description. The result of the research is that Google Classromm media really helps educators and teachers to continue to carry out the learning process in the midst of the Covid-19 virus epidemic, but there needs to be attention to the quality of learning when learning is carried out in a long distance Most of Fekonsos students of UIN SUSKA Riau still do not feel that they understand the knowledge conveyed by learning using Google Classroom.
\end{abstract}

Keyword: online learning, google classroom, covid-19 virus

\begin{abstract}
Abstrak
Penerapan pembelajaran dengan sistem Daring merupakan konsekuensi dari penyebaran Virus Covid-19 di dunia pendidikan. Google Classroom adalah media untuk membantu pendidik/pengajar dalam proses belajar. Hal ini pun telah di terapkan di lingkungan Fakultas Ekonomi dan Ilmu Sosial. Terdapat potensi adanya hambatan dalam proses pembelajaran daring dengan menggunakan google classroom di lingkungan Uin Suska riau, oleh karena itu peneliti tertarik utnuk meneliti penerapan sistem pembelajaran dengan Google classroom. Penelitian ini menggunakan metode kualitatif deskriptif dengan teknik survey. Penelitian dilakukan pada tanggal 05 Oktober 2020-15 Desember 2020 dengan jumlah responden sebanyak 390 orang mahasiswa di lingkungan Fakultas Ekonomi dan Ilmu Sosial UIN Suska Riau. Data diperoleh melalui pertanyaan-pertanyaan yang dibagikan kepada seluruh responden dalam bentuk google form kemudian data di analisis dengan uraian deskripsi. Hasil penelitian adalah media Google Classroom sangat membantu para pendidik dan pengajar untuk ettap melakukan proses pembelajaran ditengah masa pendemi virus covid-19 namun perlu adanya perhatian terhadap kualitas pembelajaran ketika pmebelajaran dilaksanakan dengan jaraj jauh. Mahasiswa Fekonsos UIN SUSKA Riau sebagian besar masih belum merasa mengerti ilmu yang disampaikan dengan pembelajaran menggunakan Google Classroom.
\end{abstract}

Kata kunci: pembelajaran online, google classroom, virus covid-19 


\section{PENDAHULUAN}

Novel Coronavirus 2019, atau nCoV-2019, adalah virus pernafasan jenis baru yang pertama kali teridentifikasi di Wuhan, Provinsi Hubei, tiongkok di pengunjung tahun 2019. Virus ini mematikan, sangat menular, dan cepat menyebar. Virus ini juga terbilang jenis baru, dalam artian virus ini tidak pernah diketahui sebelumnya dan tidak sama dengan virus-virus corona lainnya yang biasanya tersebar di antara manusia dan menyebabkan penyakit ringan seperti pilek biasa. Tujuh jenis virus corona diketahui menginfeksi manusia, termasuk virus jenis baru, yang menyebabkan penyakit-penyakit di sistem pernafasan. Empat dari ketujuh jenis ini menimbulkan sakit pilek biasa. Dua lainnya, sebaliknya dianggap menyebabkan infeksi manusia yang paling mematikan (sindrom penafasan akut berat, atau SARS, dan sindrom pernafasan Timur Tengah atau MERS) (Tess, 2020). Menurut consensus medis, virus COVID-19 tidak begitu mematikan dibandingkan SARS. Namun, virus ini lebih mudah menular. Penularan COVID-19 dari manusia ke manusia lebih tinggi dari pada SARS.

Serangan virus Covid-2019 ini pun menyebar ke seluruh dunia hingg organisasi kesehatan dunia/ World Health Organization (WHO) menetapkan peristiwa tersebut menjadi suatu phenomena dan sampai pada level Pandemic. Pandemik berasal dari bahsa Yunani Pandemos, yang artinya "semua orang", "pan”, berarti semua orang”, "demos"berate populasi. Sehingga virus Covid-2019 ini menyerang dan menularkan ke semua orang tanpa terkecuali. Wabah penyakit menular berskala besar ini bisa meningkatkan morbiditas dan mortalitas di sebuah wilayah geografis yang luas dan menimbulkan kekacauan politik, sosial, dan ekonomi.

Provinsi Riau menjadi daerah dengan penambahan yang signifikan. Berdasarkan penyataaan Kepala Dinas Kesehatan Provinsi Riau bahwa terdapat penambahan kasus untuk 5 november 2020 covid-19 sebanyak 176 kasus terkonfirmasi dengan 327 covid19 yang sembuh (Center, 2020). Berikut adalah jumlah kasus Covid-19 di riau : 
Tabel 1. Laporan media harian kasus konfirmas covid-19

\begin{tabular}{|c|c|c|c|c|c|c|c|c|c|c|}
\hline \multirow[b]{2}{*}{ NO } & \multirow[b]{2}{*}{ KABUPATEN/ KOTA } & \multicolumn{3}{|c|}{ JUMLAH KASUS } & \multicolumn{3}{|c|}{ JUMLAH KASUS SEMBUH } & \multicolumn{3}{|c|}{ JUMLAH KASUS MENINGGAL } \\
\hline & & $\begin{array}{c}\text { \$/D04 } \\
\text { NOVEMEER } \\
2020 \\
\end{array}$ & $\begin{array}{c}\text { OS } \\
\text { NOVEMBER } \\
2020 \\
\end{array}$ & $\begin{array}{c}\text { KASUS } \\
\text { KUMULATIF }\end{array}$ & $\begin{array}{c}5 / 004 \\
\text { NOVEMBER } \\
2020 \\
\end{array}$ & $\begin{array}{c}\text { 05 } \\
\text { NOVEMBER } \\
2020\end{array}$ & $\begin{array}{c}\text { KasUS } \\
\text { KUMULATIF }\end{array}$ & $\begin{array}{c}\text { S/D04 } \\
\text { NOVEMBER } \\
2020\end{array}$ & $\begin{array}{c}\text { OS } \\
\text { NOVEMBER } \\
2020\end{array}$ & $\begin{array}{c}\text { KASUS } \\
\text { KUMULATIF }\end{array}$ \\
\hline 1 & PEKANBARU & 7477 & 91 & 7568 & 6032 & 149 & 6181 & 187 & 2 & 189 \\
\hline 2 & KAMPAR & 1458 & 16 & 1474 & 1175 & 25 & 1200 & 33 & 0 & 33 \\
\hline 3 & PELALAWAN & 864 & 4 & 868 & 784 & 16 & 800 & 8 & 0 & 8 \\
\hline 4 & INDRAGIRI HULU & 356 & 0 & 356 & 224 & 38 & 262 & 5 & 0 & 5 \\
\hline 5 & INDRAGIRI HILIR & 390 & 1 & 391 & 338 & 0 & 338 & 15 & 0 & 15 \\
\hline 6 & DUMAI & 1260 & 16 & 1276 & 1053 & 16 & 1069 & 25 & 0 & 25 \\
\hline 7 & KEP. MERANTI & 128 & 0 & 128 & 108 & 1 & 109 & 0 & 0 & 0 \\
\hline 8 & BENGKALIS & 906 & 12 & 918 & 610 & 39 & 649 & 19 & 0 & 19 \\
\hline 9 & SIAK & 1194 & 9 & 1203 & 1017 & 11 & 1028 & 22 & 0 & 22 \\
\hline 10 & KUANTAN SINGINGI & 319 & 3 & 322 & 242 & 13 & 255 & 9 & 0 & 9 \\
\hline 11 & ROKAN HIUR & 392 & 9 & 401 & 288 & 6 & 294 & 11 & 0 & 11 \\
\hline 12 & ROKAN HULU & 305 & 12 & 317 & 236 & 12 & 248 & 11 & 0 & 11 \\
\hline 13 & LUAR PROVINSI RIAU & 53 & 3 & 56 & 39 & 1 & 40 & 1 & 0 & 1 \\
\hline & TOTAL & 15102 & 176 & 15278 & 12146 & 327 & 12473 & 346 & 2 & 348 \\
\hline
\end{tabular}

Sumber: corona.riau.go.id

Pada table di atas pun terlihat angka penyebaran kasus konfirmasi covid-19 di pekanbaru yang sangat besar. Peningkatan kasus konfirmasi covid-19 terlihat dari bulan oktober penyebaran hingga kini. Hal tersebut tergambarkan dari grafis di bawah ini : 
Gambar 1. Data konfirmasi covid-19

Data Konfirmasi Covid-19 Provinsi Riau

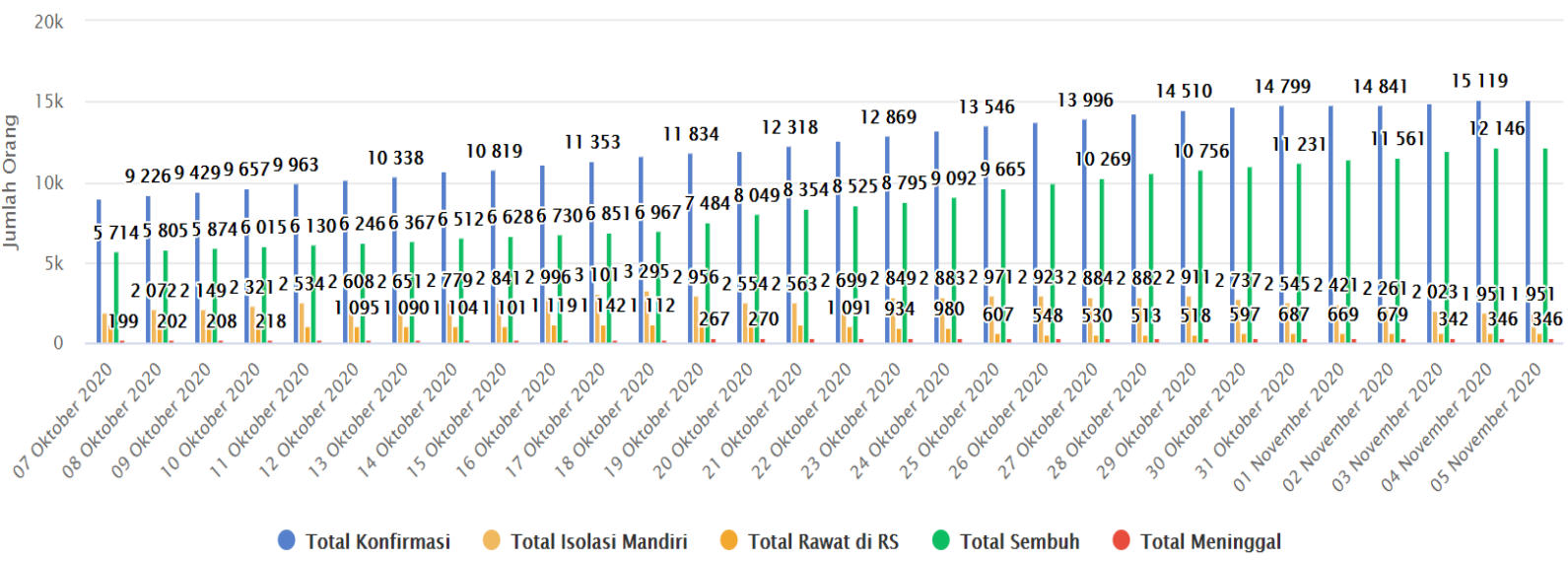

Sumber : https://corona.riau.go.id/data-statistik/

Walaupun terdapat penurunan pada angka korban meninggal dan terdapat peningkatan pada jumlah yang sembuh, namun grafik pasien terkonfirmasi terus mengalami peningkatan pula. Hal ini menandakan bahwa kasus corona-19 ini belum dianggap selesai dan tetap harus di waspadai. Untuk memutus mata rantai penyebaran covid-19 diberlakukan berbagai upaya oleh pemerintah. Tindakan pencegahan agar covid-19 tidak terus menerus menyebar dengan pembuatan kebijakan-kebijakan berupa penetapan beberapa peraturan di Indoensia diantaranya memberlakukan karantina rumah dan pembatasan sosial berskala besar. Keharusan Physical Distancing dan mengkarantina diri dirumah juga berimbas pada dunia pendidikan terutama pada tingkat pendidikan tinggi. Para pendidik sebagai pengelola pendidikan diminta aktiv dan tanggap untuk menjalankan tugas dengan bekerja dari rumah (Work From Home). Sehingga proses pembelajaran tetap terlaksana. Pendidik/ Dosen melakukan proses pembelajaran dari rumah secara Online atau Daring hingga saat ini dan akan berlanjut pada tahun pembelajaran baru yaitu 2020-2021.

Universitas Islam Negeri Sultan Syarif Kasim Riau (UIN SUSKA RIAU) menjadi salah satu universitas negeri di provinsi riau khususnya kota Pekanbaru. Pada tingkat pendidikan tinggi di riau terutama di Uin Suska Riau juga sudah melakukan instruksi pencegahan agar covid-19 
tidak menyebar di pekanbaru provinsi riau melalui upaya pemberlakuan Physical Distancing di lingkungan kampus, dosen, mahasiswa dan tendik dan pegawai. Untuk mewujudkan hal tersebut dihimbau pada lembaga formal pendidikan dalam masa wabah corona agar meniadakan proses kegiatan pembelajaran tatap muka langsung sebagaimana hari-hari biasanya.

Di tengah wabah corona yang mengisolasi ruang gerak dosen hingga harus Work From Home dalam menjalankan fungsi dan tugas dosen bukanlah suatu hal yang mampu menghentikan jalannya pendidikan dan bukan pula sebagai penghalang bagi pendidik untuk berinovasi. Covid19 yang kedatangannya membuat khawatir semua lapisan kehidupan berbangsa dan bernegara namun sisi baiknya juga menghadirkan tradisi baru pada dosen dan mahasiswa dalam bertatap muka dan dalam pemberian tugas kepada mahasiswa. Tradisi yang hanya baru tetapi juga sesuatu yang langka dilakukan saat dosen dan mahasiswa harus berkomunikasi tanpa disertai kehadiran. Tatap muka dilakukan dengan menggunakan teknologi digital terpercaya dan memudahkan dalam memberikan informasi kapan pun dan dimanapun atau dilakukan secara online/daring.

Dalam proses pembelajaran melalui daring/online kampus UIN Suska Riau mengisyaratkan untuk menggunakan media pembelajaran Google Classroom. Google Classroom $(G C)$ merupakan media pembelajaran yang di rancang untuk memudahkan dunia para pendidik, daalam merancang, membadikan dan mengelompokkan materi, penugasan/instruksi, angket tanpa kertas presentasi (Bulan \& Zainiyati, 2020).

Google Classroom dapat membantu untuk memudahkan mahasiswa dan dosen dalam proses belajar mengajar, di luar kelas dengan waktu yang telah ditetepkan sebelumnya. Google Classroom adalah suatu model pembelajaran kombinasi/campuran yang dikembangkan oleh Goolge untuk perangkat pembelajaran, bertujuan untuk menyederhanakan, pendistribusian dan instruksi tugas tanpa kertas. Selain itu, google classroom adalah layanan berbasis internet yang dirancang sebagai sebuah sistem e-learning. Hal ini dapat membantu dalam menjalankan protocol keamana covid-19 untuk tetap jaga jarak dengan orang ramai.

Beberapa hambatan tentu akan ditemukan dalam proses pembelajaran daring, sehingga mahasiswa pun pada umumnya harus mencari sendiri solusi akan menghambat yang dihadapi. Berbagai hambatan yang ditemukan selama dalam proses pembelajaran dapat berpengaruh pada psikis mahasiswa, sehingga diperlukan adanya solusi atas berbagai hambatan.misalnya 
kemampuan dalam pengelolaan stres yang dihadapi. Kondisi ini menjadi hal yang menarik diteliti mengingat sistem pembelajaran daring ini pertama kali dilakukan oleh mahasiswa secara umum.

Terdapat potensi adanya hambatan dalam proses pembelajaran daring dengan menggunakan google classroom di lingkungan Uin Suska riau, oleh karena itu peneliti tertarik utnuk meneliti penerapan sistem pembelajaran dengan Google classroom. . Sehingga di harapkan respon yang diperoleh dapat menggambarkan proses pelaksanaan pembelajaran daring ditengah pandemic covid-19 saat ini dan dijadikan informasi dasar bagi pihak-pihak terkait dalam menentukan kebijakan pembelajaran daring.

\section{TELAAH LITERATUR}

\section{Kebijakan Publik}

Perbedaan pengertiannya adalah masyarakat di artikan sebagai sistem antar hubungan sosial dimana manusia hidup dan tinggal bersama-sama. Di dalam masyarakat tersebut terdapat norma-norma atau nilai-nilai tertentu yang mengikat dan membatasi kehidupan anggotaangotanya. Dilain pihak publik diartikan sebagai kumpulan orang-orang yang menaruh perhatian, minat atau kepentingan yang sama. Tidak ada norma/nilai yang mengikat/membatasi perilaku public sebagaimana halnya pada masyarakat, karena public sulit dikenali sifat-sifat kepribadiannya (indentifikasinya) secara jelas. Sedangkan Kebijakan yang dimaksud disepadankan dengan kata policy yang dibedakan dengan kebijaksanaan (wisdom) maupun kebajikan (virtues). Winarno dan Wahab sepakat bahwa istilah 'kebijakan' ini penggunaannya sering dipertukarkan dengan istilah-istilah lain seperti tujuan (goals), program, keputusan, undang-undang, ketentuan-ketentuan, standar, proposal dan grand design (Kebijakan Publik (Teori, Proses, Dan Studi Kasus), 2014). Bagi para policy makers (pembuat kebijakan) dan orang-orang yang menggeluti kebijakan, penggunaan istilah-istilah tersebut tidak menimbulkan masalah, tetapi bagi orang di luar struktur pengambilan kebijakan tersebut mungkin akan membingungkan (Analisis Kebijakan: Dari Formulasi Ke Penyusunan Model-Model Implementasi Kebijakan Kebijakan Publik, 2012).

\section{Online Learning}

Secaram umum, belajar online merupakan suatu pembelajaran yang dilakukan secara elektronik dengan menggunakan media berbasis computer serta sebuah jaringa . belajar online dikenal juga 
dengan istilah pembelajaran E-Learning . berdasarkan artikel the University of Edinburgh (2017), E-learning merupakan cara melakukan pembelajaran tanpa harus hadir langsung ke kampus. Sedangkan menurut Harley (2001), E-learning merupakan suatu jenis belajar mengajar yang memungkinkan tersampaikannya bahan ajar ke siswa dengan menggunakan media internet, internet atau media jaringan computer lain (Afrianti, 2018).

Menurut Dabbagh dan Ritland, pembelajaran online adalah sistem belajar yang terbuka dan tersebar dengan menggunakan perkangkat pedagogi (alatpendidikan), yang dimungkinkan melalui internet dan teknologi berbasis jaringan untuk memfasilitasi pembentukan proses belajar dan pengetahuan melalui aksi dan interaksi yang berarti (Iskandar et al., 2020)

\section{Google Classroom}

Google Classroom merupakan suatu serambi pembelajaran campuran utnuk ruang lingkup pendidikan yang dapat memudahkan pengajar dalam membuat, membagikan dan menggolongkan setiap penugasan tanpa kertas (paperless). Software tersebut telah diperkenalkan sebagai keistimewaan dari Google Apps for Education yang rilis pada tanggal 12 Agustus 2014 (Rusdiana et al., 2020)

Menurut website resmi dari google, aplikasi google classroom merupakan alat produktivitas gratis meliputi email, dokumen dan penyimpanan. Classroom di desain untuk memudahkan dosen (pengajar) dalam menghemat waktu, mengelola kelas dan meningkatkan komunikasi dengan siswa-siswanya. Dengan google classroom ini dapat memudahkan peserta didik dan pengajar untuk saling terhubung di dalam dan diluar sekolah serta dapat memberikan pekerjaan rumah digital kepada mahasiswa dan memberikan tanggaoan secara langsung, kapanpun dan dimanapun (Bulan \& Zainiyati, 2020).

\section{Virus corona covid-19}

Corona virus merupakan keluarga besar virus yang menyebabkan penyakit pada manusia dan hewan. Pada manusia biasannya menyebabkan penyakit infeksi saluran pernafasan, mulai flu biasanya hingga penyakit yang serius seperti Middle East Respiratory Syndrome (MERS) dan Sindrom pernafasan akut berat/ Severe Acute Respiratory Syndrome (SARS). Coronavirus jenis baru yang ditemukan pada manusia sejak kejadian luar biasa muncul di Wuhan Cina, pada 
Desember 2019, kemudian diberi nama Severe Acute Respiratory Syndrome coronavirus 2 (SARS-Cov2), dan menyebabkan penyakit Coronavirus Disease-2019 (COVID-19) (Iskandar et al., 2020).

\section{METODE PENELITIAN}

Penelitian ini menggunakan metode kualitatif deskriptif dengan teknik survey. Penelitian dilakukan pada tanggal 05 Oktober 2020-15 Desember 2020 dengan jumlah responden sebanyak 390 orang mahasiswa di lingkungan Fakultas Ekonomi dan Ilmu Sosial UIN Suska Riau. Data diperoleh melalui pertanyaan-pertanyaan yang dibagikan kepada seluruh responden dalam bentuk google form kemudia data di analisis dengan uraian deskripsi.

\section{HASIL DAN PEMBAHASAN}

\section{PELAKSANAAN PEMBELAJARAN BERBASIS ONLINE (MEDIA GOOGLE CLASSROOM)DALAM TANGGAP WORK FROM HOME MASA PANDEMI VIRUS COVID-19 DI FAKULTAS EKONOMI DAN ILMU SOSIAL UNIVERSITAS ISLAM NEGERI SULTAN SYARIF KASIM RIAU Gambaran Responden}

Dalam penelitian ini responden merupakan mahasiswa fakultas ekonomi dan ilmu sosial UIN SUSKA Riau. Adapun jumlah responden adalah 390 mahasiswa dengan data sebaran respondennya adalah sebagai berikut :

Jenis Kelamin:

309 responses

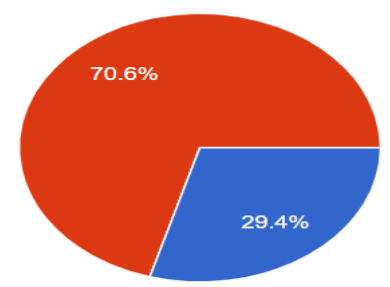

Laki-laki

Perempuan

Gambar 1. Sebaran responden berdasarkan jenis kelamin 
angkatan

309 responses

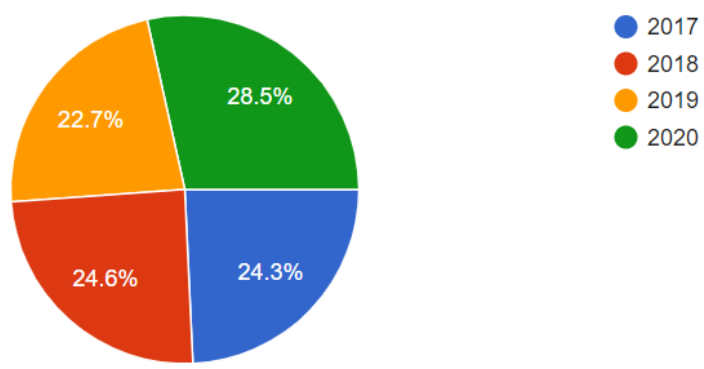

\section{Gambar 2. Sebaran responden berdasarkan angkatan belajar}

Dalam diagram diatas terlihat responden di dominasi oleh perempuan dengan persentase $71 \%$ adalah mahasiswa perempuan dan $29 \%$ adalah mahasiswa laki-laki. Serta dengan responden yang memberikan tanggapan paling banyak adalah mahasiswa angkatan tahun 2020 sebanyak 23.6\% diikuti angkatan tahun 2018 sebanyak 37.2\% serta angkatan 2017 sebanyak 20\% dan 2019 sebanyak $19.2 \%$.

Dalam penerapan sistem pembelajaran daring dengan diinstruksikan menggunakan google Class Room di lingkungan Fakultas ekonomi dan Ilmu Sosial, tanggapan mahasiswa terhadap pemelajaran tersebut sangat diperlukan untuk mengevaluasi optimalisasi pelaksanaan demi memperbaiki kualitas dan meningkatkan mutu pembelajaran. Dalam melihat gambaran pelaksanaan pembelajaran daring pada mahasiswa Fakultas Ekonomi dan Ilmu Sosial peneliti melihat dari beberapa hal yaitu: (1) media pembelajaran; (2) pemahaman terhadap media yang digunakan; (3) perasaan mengikuti pembelajaran (4) pemahaman terhadap materi dalam pembelajaran daring (5) kendala yang dihadapi (6)efektifitas.

\section{MEDIA PEMBELAJARAN}

Jenis media yang digunakan oleh responden/mahasiswa dalam pembelajaran adalah Whatsapp, Zoom, Google Meet, dan yang lainnya. Adapun data sebarannya adalah: 
Media komunikasi digital yang digunakan selain Google Class room:

389 responses
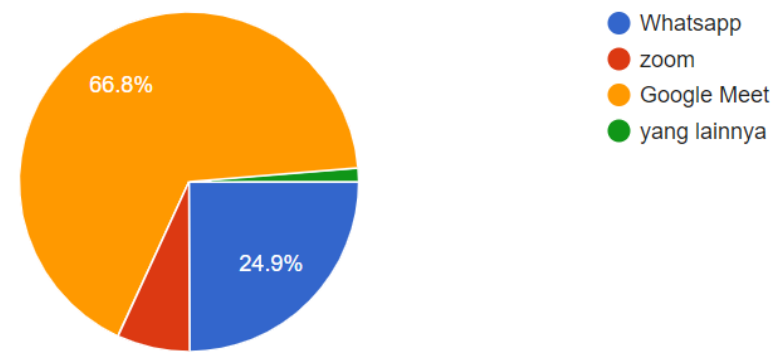

Gambar 3. Media Pembelajaran yang Digunakan

Berdasarkan gambar diatas terlihat bahwa selain menggunakan Google ClassRoom yang telah diinstruksikan pimpinan Fakultas Ekonomi dan Ilmu Sosial, pengajar/dosen juga menggunakan media lainnya untuk pembelajaran yaitu Google Meet media yang paling banyak digunakan dengan responden $66.8 \%$, whatsapp sebanyak $24.9 \%$, Zoom sebanyak $6.9 \%$ serta yang lainnya sebanyak $1.3 \%$.

Berdasarkan rapat dosen yang dilakukan sebelum perkuliahan dimulai selain menggunaka Google Classroom dosen diwajibkan menggunakan pertemuan virtual menggunakan Google Meet atau Zoom. Hal ini dilakukan untuk memaksimalkan penyampaian materi yang diberikan dosen terhadap mahasiswa secara langsung (tatapmuka virtual).dengan memaklumi kondisi mahasiswa dan keadaan ekonomi mahasiswa, maka tatap muka virtual hanya dilakukan minimal 4 kali. Dalam masa pandemi ini perusahaan Google terus berinovasi untuk memfasilitasi masyarakat di dunia pendidikan khususnya terhdap pemberlakuan e-learning. Hal ini akan sangat membantu membantu dalam mengurai perkumpulan manusia dalam jumlah banyak yang berakibat bertambahnya penyebaran virus korona hal lain juga sangat ekonomis bagi rutinitas mahasiswa dalam kegiatan pembelajaran daring masa pandemic Covid-19.

\section{Pemahaman Terhadap Tipe Media Pembelajaran}

Dalam pemahaman mahasiswa terhadap media pembelajaran yang digunakan oleh responden/mahasiswa dalam penelitian ini dapat dilihat dari hasilnya sebagai berikut: 
Pemahaman terhadap media komunikasi digital Google Class Room yang digunakan: 387 responses

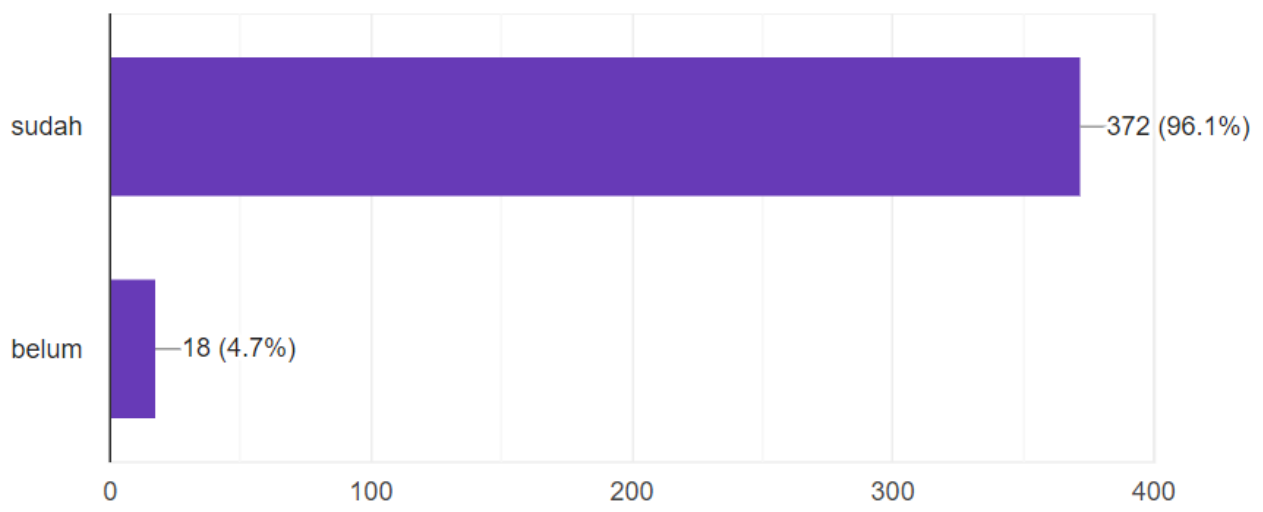

\section{Gambar 4. Data Sebaran pemahaman responden terhadap Google Classroom}

Berdasarkan gambar tersebut dapat dijelaskan bahwa pengguna media pembelajaran daring yaitu Google Classroom sebanyak $96.1 \%$ sudah tau dan $4.7 \%$ belum tau. Pada masa pandemi Covid-19 ini mengubah perilaku masyarakat Indonesia menjadi pengguna aktif internet sehingga masyarakat sangat aktif dan memili waktu banyak untuk mengeksplor aplikasi-aplikasi serta platform di dunia internet/maya. Berdasarkan data dari Kementerian Komunikasi dan Informatika RI menyebutkan penggunaan internet menunjukkan peningkatan hingga $40 \%$ (https://rri.co.id/pekanbaru/daerah/844694/penggunaan-internet-meningkat-selama-pandemi).

Dengan peningkatan penggunaan internet membuat sebagian besar mahasiswa menjadi pengguna aktif internet dan dapat mempelajari Google Classroom dengan mudah. Selain keingintahuan yang kuat dan menguasai penggunaan Google Classroom merupakan suatu keharusan di Fakultas Ekonomi dan Ilmu Sosial bagi responden, Google Classrom merupakan sebuah Platform yang mudah untuk dimengerti dan dipelajari sehingga memungkinkan untuk pengguna memhami untuk menggunakan Google Classroom sebagai media pembelajaran.

\section{Perasaan Mengikuti Perkuliahann Daring}

Perasaan responden mengikuti perkuliahan dengan sistem Daring dalam penelitian in dapat dilihat hasilnya sebagai berikut: 
rasa yang dirasakan ketika mengikuti perkuliahan daring

388 responses

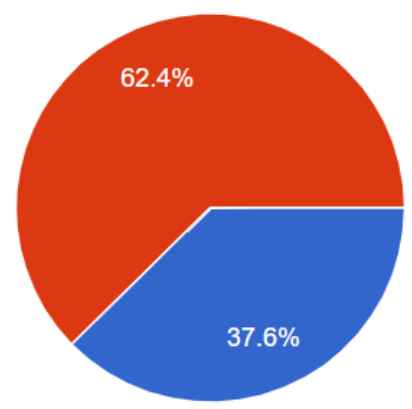

\section{Gambar 5. Perasaan Mengikuti Perkuliahan Daring}

Berdasarkan gambar diatas dapat diketahui bahwa perasaan responden/mahasiswa di lingkungan Fakultas Ekonomi dan Ilmu Sosial saat mengikuti perkuliahan dengan sistem daring mayoritas menyebutkan tidak senang sebesar $62.4 \%$ dan senang sebesar $37.6 \%$ artinya lebih dari setengah responden tidak menyukai pembelajaran dengan sistem daring.

Berdasarkan wawancara tertulis penulsi terhadap responden melalui googleform, responden menyatakan bahwa lebih memilih pembelajan dengan tatap muka/offline dikarenakan materi yang disampaikan lebih cepat dipahami oleh responden karena telah dilakukan dengan komunikasi dua arah antara dosen dan mahasiswa. Sedangkan dengan menggunakan sistem daring sebagian dosen kebanyakan hanya memberikan tugas saja tanpa memberikan pemahaman yang jelas dan mahasiswa secara umum membuat tugas dengan asal-asalan. Hal tersebut menyebabkan rasa tidak senang ketika mengikuti perkuliahan online.

Rasa senang/tidak senang bisa di ciptakan dari pola fikir, sehingga jika responden/mahasiswa dapat mengantisipasi agar dapat terus menjaga pola fikir untuk terus tetap positif dengan memberika sugesti merasakan kesenangan dalam sistem perkuliahan ini, sehinggs responden/mahasiswa Fakultas Ekonomi dan Ilmu Sosial dapat mempertahankan kondisi normal, senang dan meningkatkan minat belajar. Nurhasanah dan Sobandi (2016) mengungkapkan bahwa minat belajar ini merupakan detrminasi dari hasil belajar siswa sehingga minat belajar ini harus tetap dipertahankan. Jika hal tersebut dapat dibiasakan maka akan menjadi faktor dalam kesuksesan pembelajaran dengan sistem daring .

\section{Pemahaman Terhadap Materi yang Diberikan Melalui Google Classroom}

Pemahaman mahasiswa terhadap materi yang diberikan oleh dosen ketika mengikuti perkuliahan melalui Google Classroom dalam penelitian ini dapat dilihat sebagai berikut: 
Pemahaman terhadap materi yang diberikan melalui Google Class Room

390 responses

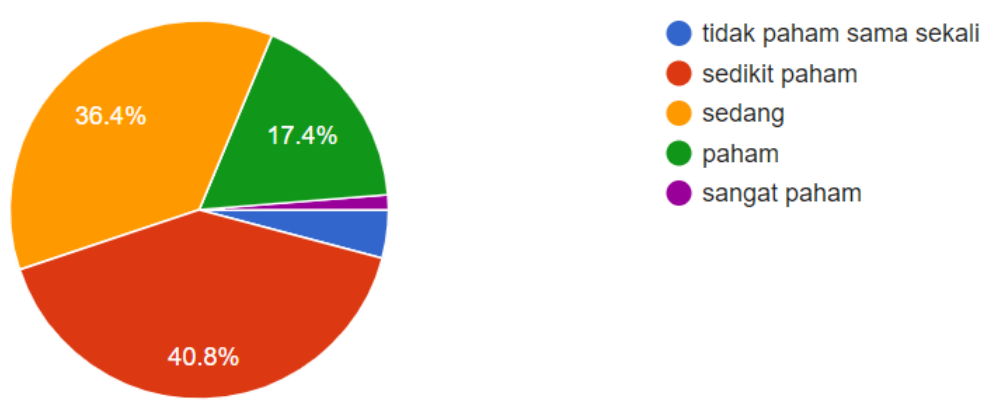

\section{Gambar 6. Pemahaman Terhadap Materi}

Berdasarkan gambar diatas diketahui bahwa pemahaman responden/mahasiswa terhadap materi yang diberikan melalui Google Classroom saat mengikuti perkuliahan dengan sistem Daring diperoleh $40.8 \%$ Sedikit paham, $36.4 \%$ sedang, $17.4 \%$ paham, $4.1 \%$ tidak paham sama sekali, dan $1.3 \%$ sangat paham.

Terdapat beberapa faktor penghambat pemahaman mahasiswa terhadap materi yang diberikan oleh dosen ketika mnegikuti perkuliahan melalui Google Classroom diantarannya adalah kebiasaan mahasiswa pada saat proses pembelajaran (Jamaluddin,2020). Saat diperberlakukan kembali sistem tatap muka secara langsung, kemudian diterapkan kembali metode ceramah secara langsung maka mahasiswa pada umumnya hanya mendengarkan. Akan tetapi, ketika sistem pembelajaran online diterapkan kembali, memahami materi dengan instruksi yang telah ada pun masih menjadi tantangan, sehingga sebagian mahasiswa merasa sulit dalam memahami materi perkuliahan.

Disisi lain, terdapat mata kuliah yang baiknya dilakukan penjelasan secara langsung. Ketika digunakan sistem Daring ini menjadi dirasa lebih sulit, karena beberapa materi menggunakan skill lab. Oleh karena itu, pemilihan media yang tepat harus dilakukan oleh dosen dan disesuaikan dengan mata kuliah yang diampu.

\section{Kendala yang Dihadapi}

Kendala yang dihadapi mahasiswa saat mengikuti perkuliahan dengan sistem daring dan menggunaka google classroom dalam penelitian ini dapat dilihat hasilnya sebagai berikut: 
Kendala yang dihadapi:

390 responses

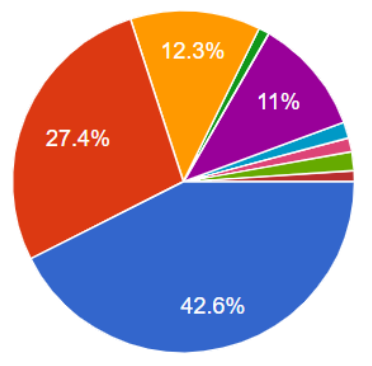

Gambar 7. Kendala yang dihadapi

Berdasarkan gambar diatas terlihat bahwa kendala mahasiswa di lingkungan Fakultas Ekonomi dan Ilmu Sosial UIN SUSKA Riau saat mengikuti perkuliahan dengan menggunakan Googgle Classroom mayotitas menyebutkan jaringan/sinyal sebanyak $42.6 \%$ dan kuota internet sebanyak 27.4\%, kemudian diikuti dengan banyaknya tugas yang diberikan sebesar $11 . \%$ dan sulit berkonsentrasi $11.2 \%$.

Dengan kondisi lokasi daerah tempat tinggal mahasiswa yang berbeda-beda, yaitu terdapat di kota, desa, kawasan yang tersedia jaringan bahkan tidak tersedia jaringan membuat mahasiswa kesulitan untuk mengikuti perkuliahan secara daring. Jaringan yang tidak stabil juga merupakan hambatan dalam proses pembelajaran dengan sistem daring. Keberadaan fasilitas jaringan merupakan hal yang utama dalam pembelajaran sistem daring, hal ini menjadi suatu hal yang berkaitan terhadap keberhasilan dalam proses belajar mengajar.

Menanggapi persoalan yang dihadapi mahasiswa dalam menjalankan fungsi mahasiswa untuk mengikuti proses belajar secara daring yaitu terbatas kuota internet. Pada Kementerian Pendidikan dan Kebudayaan membuat suatu kebudayaan tentang bantuan kuota bagi pelajar,guru, dosen dan mahasiswa selama pembelajaran jarak jauh (PJJ) sebagai bentuk respon atas keluhan akademika dalam menjalankan proses belajar mengajar. Yaitu peraturan Sekretaris Jenderal Kementerian Pendidikan dan Kebudayaan atau Kemendikbud Nomor 14 Tahun 2020 tentang Petunjuk Teknis Bantuan Kuota Data Internet Tahun 2020. Namun pada lingkungan pendidikan dibawah Kementerian Agama belum ada kebijakan yang dikeluarkan untuk membantu pelajar,guru, dosen dan mahasiswa dalam penyediaan kuota internet selama masa pandemi. Tentunya hal ini perlu menjadi suatu pertimbangan untuk keberhasilan dalam proses belajar mengajar selama masa pendemi.

\section{Keefektifan Pembelajaran dengan Google Classroom}

Efektifitas menurut responden yaitu mahasiswa di lingkungan Fakultas Ekonomi dan Ilmu Sosial UIN SUSKA Riau dalam pelaksanaan perkuliahan dengan menggunakan Google Classroom dalam penelitian ini d,apat dilihat hasilnya sebagai berikut: 
keefektifan pembelajaran dengan Google Class Room

385 responses

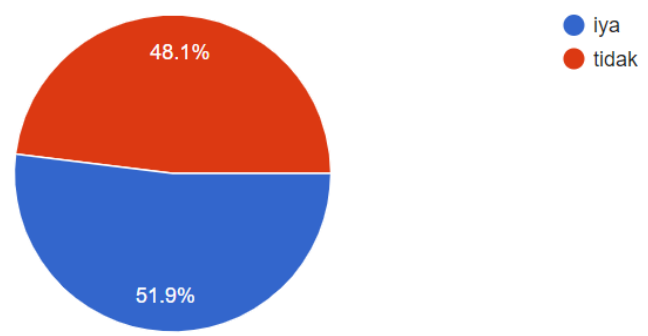

\section{Gambar 8. Efektifitas penggunaan Google Classroom}

Berdasarkan gambar diatas dapat dilihat tanggapan mahasiswa terhadap keefektifan dalam mengikuti perkuliahan dengan menggunakan Google Classroom mayoritas menyebutkan efektif $51.9 \%$ dan tidka efektif $48.1 \%$.

Pembelajaran melalui pendekatan partisipatori terlebih pada masa Work From Home akibat penyebaran virus Covid-19 terbukti efektif sebagai untuk mencapai tujuan pembelajaran sebagai perwujudan tantangan digital pendidikan tinggi abad 21 (Darlamaksana,2020)

Google memiliki posisi paling strategis untuk mengumpulkan data para penggunanya, yaitu sebesar 64.4\% (https://databoks.katadata.co.id/datapublish/2019/10/11/google-palingbanyak-kumpulkan-data-pengguna), data itu berasal dari beragam layanan yang disediakan oleh perusahaan ini dan dimanfaatkan pengguna dalam aktivitas sehari-hari, misalnya layanan surat elektronik Gmail, Google Maps, dan peramban Chrome. Google Classroom merupakan salah satu bagian dari layanan aplikasi Google untuk memfasilitasi dunia pendidikan tinggi dalam proses belajar mengajar. dengan besarnya angka pengguna Google di Indonesia maka memungkinkan untuk mahasiswa/responden menggunakan Google Classroom, sehingga google classroom media paling baik dan efektif untuk digunakan dalam proses belajar mengajar disaat masa pandemi untuk menekan angka penyebaran virus covid-19.

\section{KESIMPULAN DAN SARAN}

\section{Kesimpulan}

Dengan menggunakan Google Classroom dalam pembelajaran daring sebagai bentuk pencegahan virus covid-19 sudah dapat diterima oleh mahasiswa atau komponen dalam institusi. Terlebih jika pihak kampus dan para stakeholder kebijakan dalam penerapan sistem pembelajaran daring dapat memenuhi berbagai komponen esensial dalam pembelajaran akan menjadi lebih efektif, seperti kemudahan dalam fasilitas akses, model pembelajaran yang aktif dan inovasi untuk menghindari 
biar dan ketidak pahaman dalam pembelajaran dan dapat terus memunculkan perasaan positif di kemudian hari bagi civitas akademika Fakultas Ekonomi dan Ilmu Sosial.

\section{Saran}

Perlu adanya upaya secara terus menerus dalam penyesuaian sistem belajar di masa pandemi wabah covid-19 ini. Penyesuaian dilakukan untuk menjaga dan meningkatkan kualiats dan kuantitas belajar dan mengajar. diperlukannya dukungan yang baik dari pihak kampus untuk mengakomodasi dalam keberlangsungan proses belajar dan mengajar serta dibutuhkan riset yang lebih dalam terkait optimalisasi sistem pembelajaran secara daring terkhusus dalam penggunaan google classroom.

\section{DAFTAR PUSTAKA}

Abdul Wahab, Solichin. 2004. Analisis Kebijaksanaan dari Formulasi keImplementasi Kebijaksanaan Negara. Jakarta: Bumi Aksara.

Afrianti, W. E. (2018). PENERAPAN GOOGLE CLASSROOM DALAM PEMBELAJARAN AKUNTANSI ( Studi Pada Program Studi Akuntansi Universitas Islam Indonesia) SKRIPSI Oleh: Nama : Wahyuni Eka Afrianti FAKULTAS EKONOMI UNIVERSITAS ISLAM INDONESIA YOGYAKARTA. 1-122. https://dspace.uii.ac.id/handle/123456789/6173

Analisis Kebijakan: Dari Formulasi ke Penyusunan Model-Model Implementasi Kebijakan Kebijakan Publik. (2012). PT. Bumi Aksara.

Bulan, S., \& Zainiyati, H. S. (2020). Pembelajaran Online Berbasis Media Google Formulir dalam Tanggap Work From Home Masa Pandemi Covid-19 di Madrasah Ibtidaiyah Negeri (MIN) 1 Paser. SYAMIL: Jurnal Pendidikan Agama Islam (Journal of Islamic Education), 8(1), 15-34. https://doi.org/10.21093/sy.v8i1.2300

Center, M. (2020). Angka Kesembuhan Pasien Covid-19 Sudah Mencapai 80 Persen. Media Center.

Iskandar, Masthura, S., \& Oktabiyana, C. (2020). Penerapan Sistem Pembelajaran Daring Pada Mahasiswa Keperawatan Universitas Abulyatama. Jurnal Dedikasi Pendidikan, 4(2), 323332.

Kebijakan Publik (Teori, Proses, dan Studi Kasus). (2014). CAPS (Center Academic Publishing Service).

Rusdiana, A., Sulhan, M., Arifin, I. Z., \& Kamludin, U. A. (2020). Penerapan Model POE2WE Berbasis Blended Learning Google Classroom Pada Pembelajaran Masa WFH Pandemic Covid-19. Scientific Writing of the Bandung State Islamic University 2020, 1-10.

Tess, P. (2020). Panduan Kesiapsiagaan Hadapi Virus Corona. PT Elex Media Komputindo. 